J. Lake Sci. (湖泊科学), 2011, 23(5): 738-746

http: //www. jlakes.org. E-mail: jlakes@niglas.ac.cn

(C) 2011 by Journal of Lake Sciences

\title{
洱海湖滨带植被特征及其影响因素分析”
}

\author{
厉恩华 ${ }^{1,2}$,王学雷 ${ }^{1,2}$, 蔡晓斌 ${ }^{1,2}$, 王晓艳 ${ }^{1}$,赵素婷 ${ }^{1}$ \\ ( 1 : 中国科学院测量与地球物理研究所, 武汉 430077) \\ $(2:$ 湖北省环境与灾害监测评估重点实验室,武汉 430077$)$
}

\begin{abstract}
摘 要: 2009 年 5 至 12 月对洱海湖滨带植被进行了 3 次调查, 共鉴定出维管植物 47 科 108 属 145 种,其中乔灌木 15 种、 湿生草本植物 75 种、挺水植物 15 种、浮叶和漂浮植物各 7 种、沉水植物 26 种; 有红柳 (Salix cavaleriei)、菰 (Zizania latifolia)、菱 (Trapa natans) 和黄丝草 (Potamogeton maackianus) 等 15 个植物群落, 水生植物覆盖面积占洱海面积的 $8 \%$, 各点 位平均物种数和生物量分别为 9 个和 $12.5 \mathrm{~kg}(\mathrm{FW}) / \mathrm{m}^{2}$, 沉水植物 Margalef 物种丰富度指数为 1.8706 . 结合资料分析表 明: 经 10 余年的治理和修复, 洱海植物多样性有所提高, 北部植物多样性降低的局面得到改善, 但存在着湖滨带狭窄、挺 水植物群落类型单调、植被覆盖面积变小、固有区系成分有待恢复等问题. 应加强缓冲区建设, 以增强湖滨带功能, 提高 水体透明度, 增加洱海植被覆盖面积.
\end{abstract}

关键词: 洱海;湖滨带;生态修复;水生植物;演变

\section{Features of aquatic vegetation and the influence factors in Erhai lakeshore wetland}

\author{
LI Enhua ${ }^{1,2}$, WANG Xuelei ${ }^{1,2}$, CAI Xiaobin ${ }^{1,2}$, WANG Xiaoyan ${ }^{1} \&$ ZHAO Suting $^{1}$ \\ (1: Institute of Geodesy and Geophysics, Chinese Academy of Sciences, Wuhan 430077, P. R. China) \\ (2: Key Laboratory of Monitoring and Estimate for Environment and Disaster of Hubei Province, Wuhan 430077, P. R. China)
}

Abstract: The vascular flora in Lake Erhai wetland was investigated from May to December in 2009, and we found 145 species belonged to 108 genera in 47 families, including 15 trees and shrubs, 75 hygrophytes, 15 emergent macrophytes, 26 submerged macrophytes, 7 floating-leaved and floating plants, respectively. The wetland held 15 communities, such as Salix cavaleriei, Zizania latifolia, Trapa natans and Potamogeton maackianus comm. Aquatic vegetation covered about $8 \%$ of total water area of the lake, and the average species number and biomass were 9 and $12.5 \mathrm{~kg}(\mathrm{FW}) / \mathrm{m}^{2}$ in exploring sites, respectively. Richness index of Margalef species was 1.8706 in submerged macrophyte zone. Analysis with combinations of existing data indicated that plant diversity increased after enhancing management and lakeshore wetland restoration in the recent ten years and improved the situation of plant diversity decreasing in the northern lake. However, many problems still exist in the lakeshore wetland, such as narrow lakeshore areas, monotonous emergent macrophyte in the community, low coverage of aquatic vegetation, and the inherent flora ingredient to be restored. In order to improve functions of the lakeshore wetland, to increase water transparency and to advance the coverage of aquatic vegetation, we strongly suggest constructing the buffer areas.

Keywords: Lake Erhai; lakeshore wetland; ecological restoration; aquatic plant; evolution

湖滨带是湖泊流域中陆地生态系统和水域生态系统之间的过渡与缓冲区域, 是水陆生态系统间的一个 重要的生态交错带, 也是湖泊的一道保护屏障. 健康的湖滨带由陆向辐射带、水位变幅带和水向辐射带组 成 ${ }^{[1]}$. 因湖盆形态和基质类型不同, 其两向辐射带的宽度因湖而异.

湖滨带的功能主要包括三个方面:一是环境功能, 即湖滨带的截污、过滤、改善水质、控制沉积和侵蚀等 功能; 二是生态功能, 包括湖滨带保持生物多样性, 提供鱼类繁殖、鸟类栖息的场所, 调蓄洪水, 稳定相邻生

* 国家水体污染控制与治理科技重大专项项目 (2008ZX07105-004,2008ZX07102-005) 和中国科学院知识创新工 程重要方向性项目 (KZCX22YW2141) 联合资助. 2010-10-19 收稿;2011-01-18 收修改稿. 厉恩华, 男, 1963 年 生,博士, 副研究员; E-mail:lieh@ whigg. ac. cn. 
态系统的功能; 三是经济和美学价值, 包括资源再生、教育科研、美学、经济价值等 ${ }^{[2]}$. 随着人口增长和经济 发展, 湖滨带的开发利用不断加剧, 围垦、养殖、侵占等不合理的资源开发严重影响湖滨带的结构和功能, 导致其生态系统不稳定, 湖滨带生态环境功能退化 ${ }^{[3]}$. 近年来随着对湖泊治理研究的不断深人, 逐步认识 到健康的湖滨带是湖泊生态系统健康的前提和基础, 有关湖滨带恢复和重建的研究逐渐成为生态学研究 的重点和热点 ${ }^{[4-5]}$, 如何更好地发挥湖滨带的生态环境功能, 使其为人类服务也日益成为人们关注的 焦点.

在过去的几十年间, 由于自然演变和人类的干扰, 洱海湖滨带植被经历了几个演变阶段, 优势植被发生 了重大改变. 植物作为生态系统的初级生产者和生态系统的基本构架, 一直是人们关注的焦点. 自 1950s 至 $1990 \mathrm{~s}$ 有关洱海植被的研究论文有数篇, 但在开展 “三退三还” 和实施洱海治理、修复以来的 10 余年间, 少有 洱海水生植被的完整资料. 为探明这些措施对洱海湖滨带植被的影响, 本研究于 2009 年对洱海湖滨带进行 了三次比较全面的调查, 以期为洱海湖滨带的进一步治理提供参考.

\section{1 洱海自然概况}

洱海 $\left(25^{\circ} 36^{\prime}-25^{\circ} 58^{\prime} \mathrm{N}, 100^{\circ} 06^{\prime}-100^{\circ} 18^{\prime} \mathrm{E}\right)$ 位于云南省西部大理白族自治州境内, 为云南省 第二大湖, 是一个典型的内陆断陷湖泊, 属澜沧 江-湄公河水系. 洱海南北长 $42.5 \mathrm{~km}$, 东西宽 $8.4 \mathrm{~km}$, 平均水深为 $10.6 \mathrm{~m}$, 面积 $251.3 \mathrm{~km}^{2}$, 蓄水 量达 $27.4 \times 10^{8} \mathrm{~m}^{3}$. 湖岸线长 $127.9 \mathrm{~km}$ (高程为 $1974 \mathrm{~m}$ 时), 湖泊岸线发育系数为 2.1 . 洱海流 域属典型的中亚热带西南季风气候, 气候温和, 日照充足, 干湿季明显, 每年 11 月至翌年 5 月 为旱季, 6 月至 10 月为雨季. 湖区年平均气温 $15.1{ }^{\circ} \mathrm{C}$. 多年平均降雨量 $1048 \mathrm{~mm}$. 主要补给水 为大气降水和人湖河流, 北有弥苴河、罗时江, 西部汇有苍山十八溪水, 南纳波罗江, 东有海潮 河、凤尾阱、玉龙河等汇人, 出湖河流仅有西 洱河 ${ }^{[6]}$.

\section{2 调查方法}

为弄清洱海湖滨带尤其是已修复区 (西岸、 南部) 湖滨带植物多样性现状,于 2009 年 5 月、8 月和 12 月对洱海湖滨带植被进行三次调查, 方 法是: 沿洱海湖滨带共设 51 条垂直于岸线的样 带(图 1), 每样带设水线上 (至标高 $1974.3 \mathrm{~m}$ )、 浅水区 (水深 $1-2 \mathrm{~m}$ ) 和深水区 (水深 $3-4 \mathrm{~m}$ ) 三 个采样点,水线上的乔灌木层设 5 个 $5 \mathrm{~m} \times 5 \mathrm{~m}$

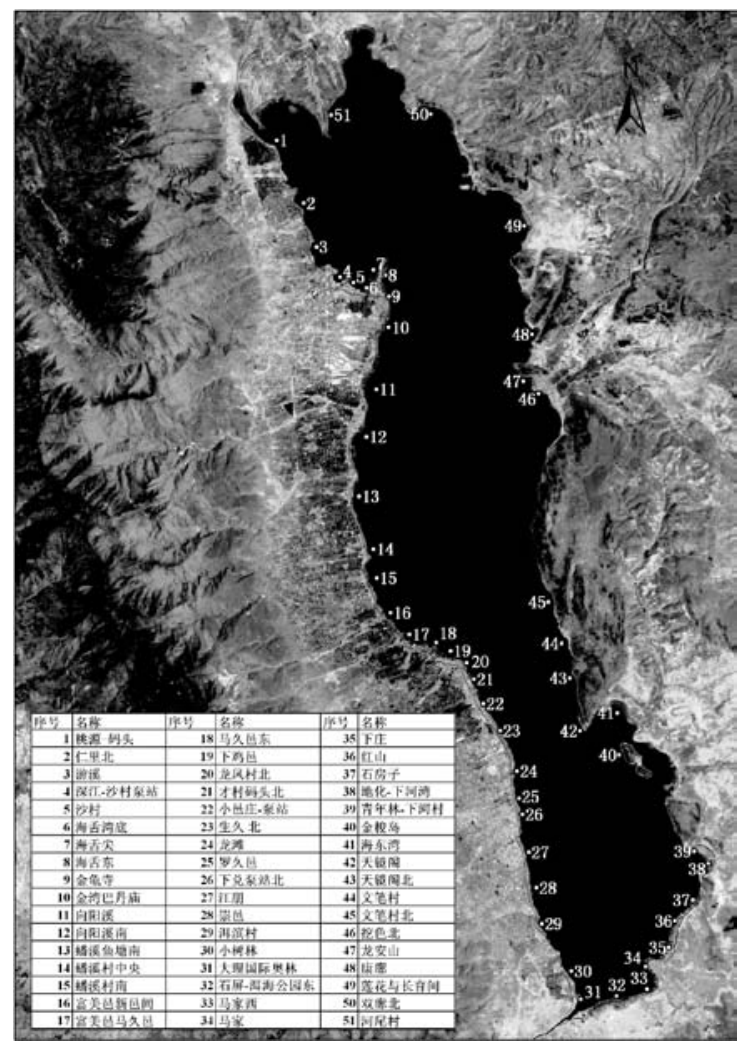

图 1 洱海湖滨带植被调查采样点分布

Fig. 1 The sampling sites distribution in Erhai lakeshore wetland aquatic vegetation investigation 的样方, 记录植物种类、株数、盖度、胸径等; 湿生 草本带设 5 个 $1 \mathrm{~m} \times 1 \mathrm{~m}$ 的样方, 记录植物种类、株数、盖度、生物量等; 挺水带设 5 个 $1 \mathrm{~m} \times 1 \mathrm{~m}$ 的样方, 记录 植物种类、盖度、高度、生物量; 浮叶、沉水带用随机小样方法 $(20 \mathrm{~m} \times 20 \mathrm{~cm})$ 调查植物的种类、生物量. Margalef 物种丰富度指数用 $D=(S-1) / \ln N$ 计算, 式中 $S$ 为物种的数目, $N$ 为位点所有物种个体总数 (沉水植物 用生物量) ; 湖滨带水生植被覆盖面积的测算: 利用声纳原理测定沉水植被分布的下线, 浮叶植物和挺水植 物直接通过 GPS 定位计算, 湖滨带上线以 $1974.3 \mathrm{~m}$ 高程线计. 


\section{3 结果}

\section{1 植物组成与多样性}

通过调查并结合已有资料 ${ }^{[6-11]}$, 洱海湖滨带有维管植物 47 科 108 属 145 种, 含属种数较多的科有禾本 科(Gramineae) (19 属, 22 种, 下同)、菊科 (Compositae) $(13,13)$ 、莎草科 (Cyperaceae) $(6,14)$ 、水鳖科 (Hydrocharitaceae) $(5,5)$ 、玄参科 (Scrophulariaceae) $(4,5)$ 、豆科 (Leguminosae) $(4,4)$ 和苶科 (Polygonaceae) $(2,5)$. 含种类较多的属有眼子菜属 (Potamogeton) (12 种, 下同)、芓荠属 (Heleocharis) (5)、莎草属 (Cyperus) (4) 和苶属 (Polygonum) (4), 包括 5 个生活型, 即挺水植物 (15 种, 下同)、浮叶植物 (7)、漂浮植物 (7)、沉水 植物 (26)、湿生草本 $(75)$ 以及湖滨带乔灌木 $(15)$.

常见的挺水植物有稀 (Zizania latifolia)、芦苇 (Phragmites australis)、荣莽 (Heleocharis dulcis) 和香蒲 (Typha orientalis) 等, 由于湖滨带修复工作的陆续展开, 一些观赏和园艺种类也补充到湖滨带, 如菖蒲 (Acorus calamus)、黄花或尾 (Iris wilsonii) 和千屈菜 (Lythrum salicaria) 等, 莲 (Nelumbo nucifera) 显然不是湖滨 带的固有区系成分,也是随着湖滨带修复工作的开展引入湖滨带的.

浮叶植物有眼子菜 (Potamogeton distinctus)、两栖苶 (Polygonum amphibium)、菱 (Trapa natans) 和荇菜 (Nymphoides peltatum) 等, 睡莲 (Nymphaea tetragona) 也是后来引入湖滨带的种类.

漂浮植物种类不多, 但在局部湖湾盖度很大, 影响了水面下植物的发育, 凤眼莲 (Eichhornia crassipes) 在 个别湖湾或原鱼塘区已达郁闭状态, 常见的还有水第 (Hydrocharis dubia)、苹 (Marsilea quadrifolia)、满江红 (Azolla imbricata) 等,槐叶苹(Salvinia natans) 已很少见.

洱海的沉水植物比较丰富, 以眼子菜科和水鳖科植物为主, 常见的有菹草 (Potamogeton crispus)、黄丝草 ( $P$. maackianus $) 、$ 马来眼子菜 $(P$. malaianus $) 、$ 红线草 $(P$. pectinatus $) 、$ 穿叶眼子菜 $(P$. perfoliatus $) 、$ 黑藻 (Hydrilla verticillata) 和苦草 (Vallisneria sp.) 等. 文献中有记录的一些种类, 在本次调查中没有采到, 如角果 藻 (Zannichellia palustris)、水篮 (Blyxa japonica)、水毛莨 (Batrachium bungei) 和石龙尾 (Limnophyla sessilifolia) 等, 海菜花 (Ottelia acuminata) 在湖滨带的数处发现, 但种群非常小, 并为人工栽培.

湖滨带的湿生草本, 多在水线附近及其以上分布, 构成滩地和林下的地被层, 多为禾本科、莎草科、菶科 和菊科杂草,虽然以往的文献记录并不多,但都应是湖滨带的固有区系成分.

湖滨带的乔灌木种类在以往的文献中并无记录, 洱海湖滨带人为干扰强烈, 加之水位的变化, 是否为湖 滨带固有种类难以断定, 其中红柳 (Salix cavaleriei) 、高山榕 (Ficus altissima)、多花萻薇 (Rosa multiflora) 和滇 合欢 (Albizia simeonis) 等可能是洱海湖滨带的固有成分, 而水松 (Glyptostrobus pensilis)、水杉 (Metasequoia glyptostroboides)、三角梅 (Bougainvillea spectabilis)、金边叶槐 (Sophora xanthantha)、紫薇 (Lagerstroemia india) 和桉树 (Eucalyptus robusta) 等可能是湖滨带修复所致, 而秋华柳 (Salix variegata) 仅在洱海西岸发现一丛, 是 否为固有分布, 尚待研究.

各位点的物种数 1 至 14 不等, 平均为 9 个 (图 2), 其生物量也差异悬殊, 在 $75-38056 \mathrm{~g}(\mathrm{FW}) / \mathrm{m}^{2}$ 之间, 平均为 $12.5 \mathrm{~kg}(\mathrm{FW}) / \mathrm{m}^{2}$ (图 3), 物种数和生物量较大的区域为金龟寺以北的北部湖湾区 (平均物种数 11 ,

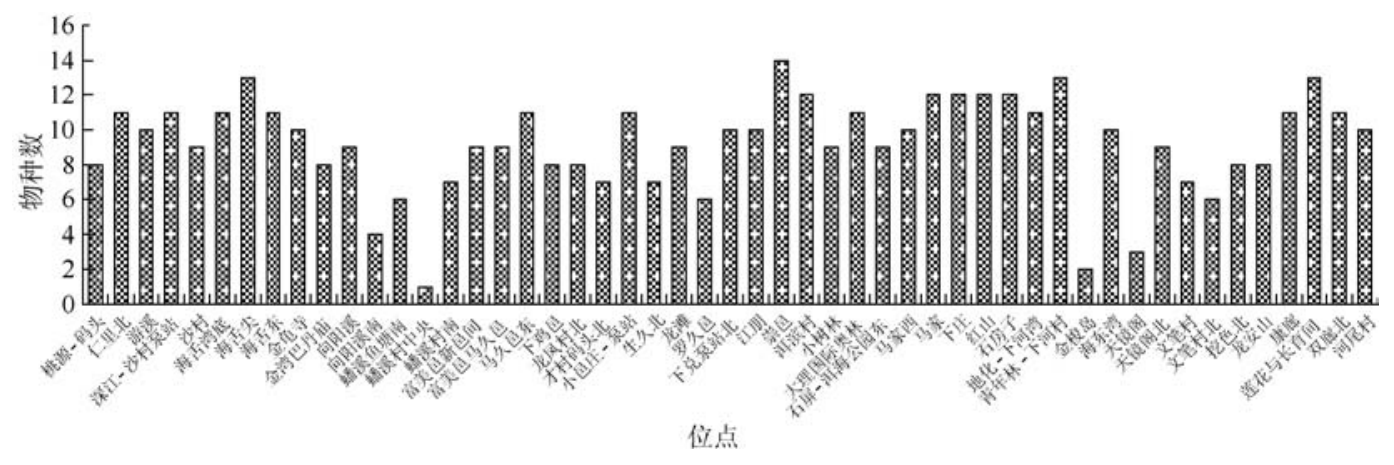

图 2 洱海湖滨带不同采样点物种数比较

Fig. 2 Comparison of the number of species in different sampling sites of Erhai lakeshore wetland 
平均生物量 $15.2 \mathrm{~kg}(\mathrm{FW}) / \mathrm{m}^{2}$, 下同)、蟠溪村南至才村码头北以富美邑为核心的西部湖湾区 $(8,16.4)$ 、罗久 邑以南至石房子的南部区域 $(11,16.3)$ 以及东部不连续的湖湾区 (康廊湾、挖色湾、海东湾等) $(10,16.2)$.

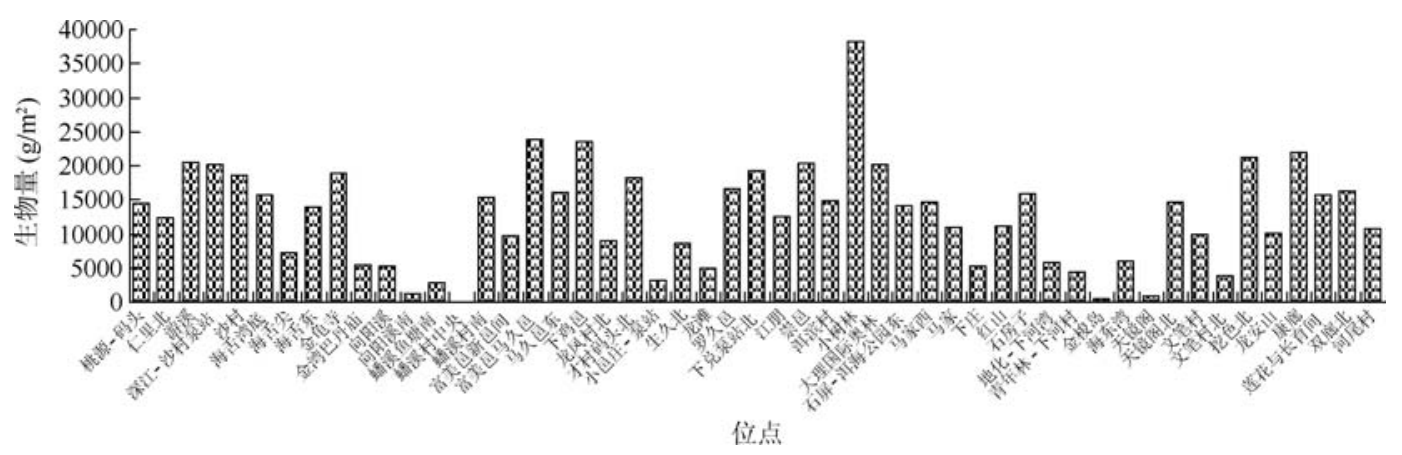

图 3 洱海湖滨带不同采样点生物量比较

Fig. 3 Comparison of the biomass in different sampling sites of Erhai lakeshore wetland

由于洱海湖滨带不完整, 陆上样方不充分 (乔灌木和湿生草本), 根据随机小样方计算洱海湖滨带 (主要为沉水植物) 的 Margalef 物种丰富度指数为 1.8706 , 各采样点的多样性指数见图 4 .

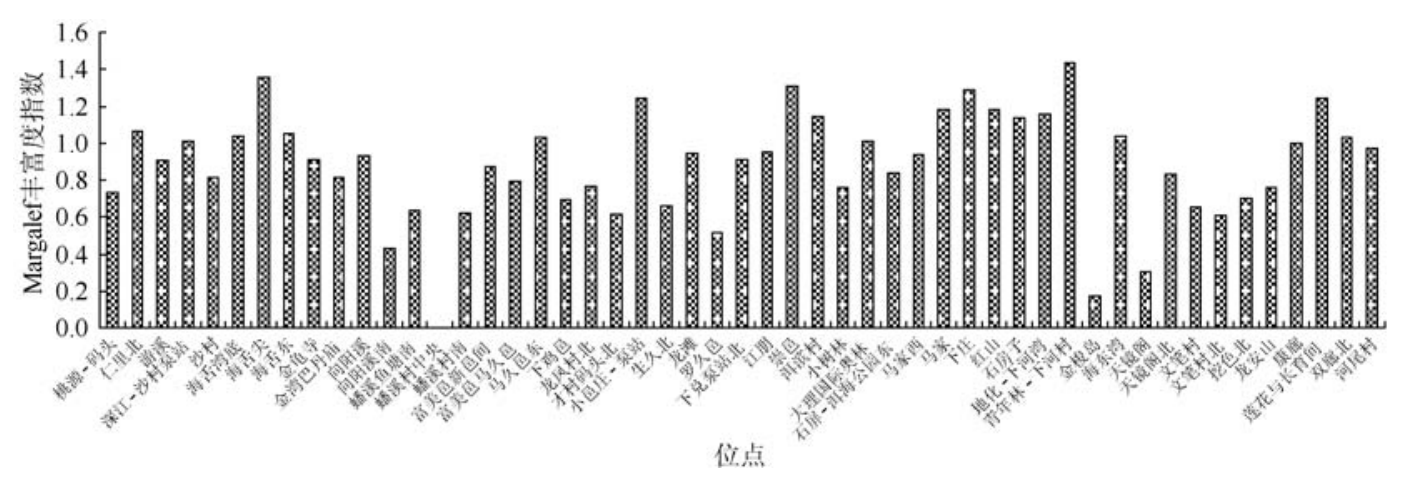

图 4 洱海湖滨带不同采样点 Margalef 物种丰富度指数比较

Fig. 4 Comparison of Margalef species richness indices in different sampling sites of Erhai lakeshore wetland

\section{2 群落类型及其分布}

洱海湖滨带植被依据生活型和优势度可分为 15 个植物群落, 分别属于乔灌木、挺水植物、浮叶植物、沉 水植物 ( 图 5).

3.2.1 乔灌木 除东部陡岸带外红柳群落在洱海湖滨带广泛分布, 成为目前湖滨带最具优势的防护林外, 不 同区段的乔灌带平均宽 $56 \mathrm{~m}$, 平均长度 $200 \mathrm{~m}$; 在以西部和南部为重点调查的 19 个位点中, 现有红柳群落的 平均盖度为 $44.7 \%$ (最大盖度为 $70 \%$, 最小为 $14 \%$ ), 伴生的 (也可能是修复时配置的) 主要物种为池杉 (Taxodium ascendens)、水杉 (Salix sp.)、柳 (Salix sp.) 、加拿大杨 (Populus Canadensis)、萻薇和秋华柳等, 其 中红柳占绝对优势, 其平均盖度为 $39.8 \%$ (最大盖度为 $67.6 \%$, 最小为 $10 \%$ ), 平均株数为 $5.5(5 \mathrm{~m} \times 5 \mathrm{~m}$ 样 方), 平均胸径为 $13.6 \mathrm{~cm}$. 林下地被层构成湖滨带湿生植物的主要来源, 但其盖度与上层盖度呈相反的 变化.

3.2 .2 挺水植物 由于自然因素、人为干扰以及后来湖滨带修复的影响, 目前的洱海湖滨带存在最多的是菰 群落, 以西岸最多, 不同区段面积差异很大, 群落盖度 $18 \%-100 \%$ 不等, 以菞为绝对优势的群落居多, 伴生种 主要有芦苇、李氏禾 (Leersia hexandra)、水花生 (Alternanthera philoxeroides)、凤眼莲、水蓼 (Polygonum hydropiper ) 等. 芦苇群落比较少见, 主要分布在西岸的马久邑和南部的马家一带, 多为人工修复而来, 局部形成 


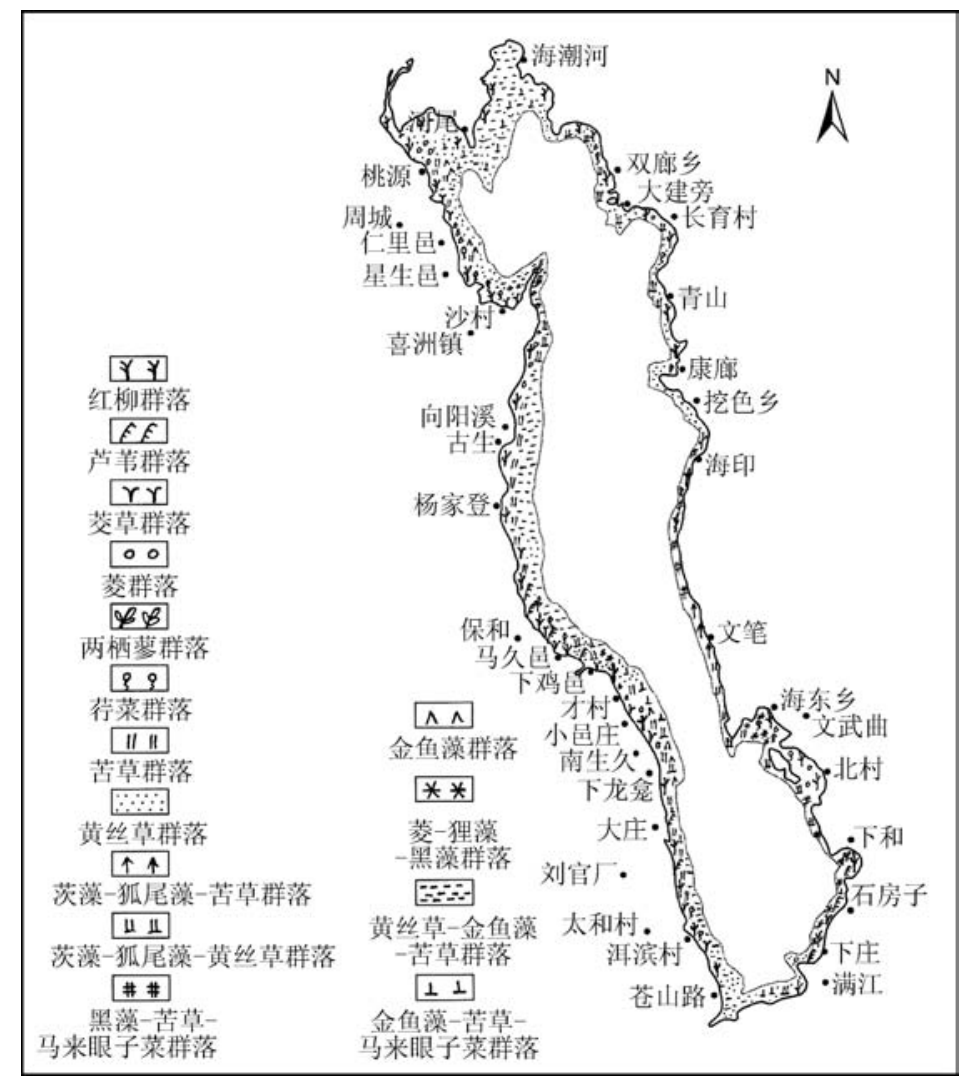

图 5 洱海水生植被分布示意图 (2009 年)

Fig. 5 Sketch map of the aquatic vegetation distribution of Lake Erhai (2009)

单优群落, 群落周围有凤眼莲等.

3.2 .3 浮叶植物 (1) 菱群落在洱海的湖湾中几乎都有分布, 成为湖滨带浮叶植物的主要类群, 往往在水面 上形成单优群落, 东岸的沙邑、海东湾, 南部的红山湾, 西岸的桃源、沙村、下鸡邑等湖湾都有大面积分布, 群 落中伴有黄丝草、金鱼藻 (Ceratophyllum demersum) 、苦草、荇菜、穗花狐尾藻 (Myriophyllum spicatum) 、黑藻和 竹叶眼子菜 (Potamogeton malaianus) 等. (2) 两栖蓼群落在洱海多有分布, 在花期, 白色或淡紫色的花在湖滨 带易见, 在莲花湾、仁里北、沙湾、海舌、富美邑新邑间、崇邑、石房子、下河湾等处的湖湾有分布, 但生物量不高, 群落盖度 30\%-70\%, 远小于菱, 群落中两栖苶的生物量在 $140-690 \mathrm{~g} / \mathrm{m}^{2}$. (3) 荇菜群落在洱海湖滨带也多有 分布, 因受风浪的影响, 以湖湾和避风处最多, 密度高的湖湾形成单优群落, 生物量在 $400-2645 \mathrm{~g}(\mathrm{FW}) / \mathrm{m}^{2}$ 之间, 在康廊、仁里、沙村、马久邑、洱滨村以及南部的马家、石房子等湖湾有分布, 由于经过了湖滨带修复, 有些湖湾为人工引种所致. 漂浮植物由于其自身的移动性, 本文未单独列出, 但在一些湖湾、池塘或者挺水 植物群落的间隙处, 苹和满江红可以布满水面; 局部区域的风眼莲和水花生也形成郁闭的群落, 对水下动植 物的生存带来不利影响.

3.2 .4 沉水植物 洱海湖滨带的沉水植物就种类而言远比长江中下游湖泊丰富, 群落类型也多样, 如:

(1) 黄丝草群落: 黄丝草是目前洱海存在的最丰富的沉水植物, 在北部、东西两岸湖湾以及南部都广泛 存在, 北部湖区以沙村湾以北、西部的马久邑湖湾、东岸的康廊湾, 南部的洱滨村以及马家一带都有大量分 布, 生物量在 $6630-29950 \mathrm{~g}(\mathrm{FW}) / \mathrm{m}^{2}$ 之间, 伴生种主要为狐尾藻、金鱼藻、黑藻、菱和光叶眼子菜 (Potamogeton lucens) 等. 
(2) 苦草群落: 苦草在洱海湖滨带分布也较为丰富, 西岸主要分布在仁里至桃源、向阳溪至蟠溪以及江 朋一带, 岸线较直和鱼塘较少的区段; 在东岸主要是金梭岛至天镜阁一带, 底质为沙砾质、风浪作用比较强 烈的区域; 苦草群落中, 苦草生物量在西岸为 $930-6580 \mathrm{~g}(\mathrm{FW}) / \mathrm{m}^{2}$, 东岸较低, 在 $300-440 \mathrm{~g}(\mathrm{FW}) / \mathrm{m}^{2}$ 之 间,伴生种主要为黑藻、金鱼藻、狐尾藻、茨藻 (Najas marina) 、黄丝草、马来眼子菜和穿叶眼子菜等.

(3) 金鱼藻群落: 以金鱼藻为优势的群落不多, 主要分布在游溪和生久北的湖湾, 生物量分别为 9950 和 $6000 \mathrm{~g}(\mathrm{FW}) / \mathrm{m}^{2}$, 伴生种主要为黄丝草、狐尾藻、黑藻、马来眼子菜和苦草等.

除了上述单一种群明显占优势的群落外,还有一些共优或几种占主要优势的群落类型：

(4) 黄丝草-金鱼藻-苦草群落: 该类型的群落主要分布在北部的河尾、沙村湾的东部、蟠溪至下鸡邑湖湾以 及洱滨村一带, 在南部主要分布在石屏至洱海公园东一带; 该类型群落的黄丝草、金鱼藻、苦草的平均生物量 分别为 $6150 、 2979 、 2347 \mathrm{~g}(\mathrm{FW}) / \mathrm{m}^{2}$, 其主要伴生种为黑藻、马来眼子菜、菱、狐尾藻、光叶眼子菜、红线草、两 栖壦和荇菜等.

（5）金鱼藻-苦草-马来眼子菜群落:该类型分布在北部的桃源村与桃源码头之间的区域,西部的龙风 村北以及龙滩下兑原站北区域, 在南部主要分布在马家至石房子一带; 在该类型群落中金鱼藻、苦草、马来 眼子菜的平均生物量分别为 $4148 、 2621 、 1490 \mathrm{~g}(\mathrm{FW}) / \mathrm{m}^{2}$, 其群落的伴生植物有黄丝草、狐尾藻、黑藻、红线 草、穿叶眼子菜、菱等.

(6) 苦草-狐尾藻一黄丝草群落: 该群落在西岸主要分布在金湾和小邑庄洜站南相对较直的湖滨带, 东 岸分布在双廊北、莲花与长育间以及天镜阁以北的区域, 在南部主要分布在波罗江口以东的下庄一带. 苦 草、狐尾藻、黄丝草在该类型群落的平均生物量分别为 $3000 、 1530 、 1000 \mathrm{~g}(\mathrm{FW}) / \mathrm{m}^{2}$, 伴生植物为黑藻、金鱼 藻、马来眼子菜、菱、红线草、扭叶眼子菜 (Potamogeton intortifolius)、荇菜等.

(7) 菱-狸藻 (Utricularia aurea) - 黑藻群落: 该群落分布在东部的海东湾、西部的才村码头北的废弃鱼塘 以及南部的红山湾、下河湾区域, 群落中菱的平均生物量为 $2689 \mathrm{~g}(\mathrm{FW}) / \mathrm{m}^{2}$, 在海东湾, 狸藻在群落的生物 量可达 $1125 \mathrm{~g}(\mathrm{FW}) / \mathrm{m}^{2}$, 该类型群落中, 黑藻的平均生物量为 $521 \mathrm{~g}(\mathrm{FW}) / \mathrm{m}^{2}$, 伴生种主要为狐尾藻、苦草、 金鱼藻、马来眼子菜、扭叶眼子菜、荇菜、穿叶眼子菜、黄丝草和水鳖 (Hydrocharis dubia) 等.

（8）黑藻-苦草-马来眼子菜群落: 该群落分布在东岸的文笔村以北至龙安山一带, 群落中黑藻、苦草、 马来眼子菜的平均生物量分别为 $4788 、 1990 、 571 \mathrm{~g}(\mathrm{FW}) / \mathrm{m}^{2}$, 伴生种有黄丝草、狐尾藻、红线草、光叶眼子 菜、金鱼藻、穿叶眼子菜和菱等.

(9) 茨藻-狐尾藻-苦草群落: 该群落类型分布在文笔村稍南的村边近似湖湾, 风浪相对小, 群落中茨藻的 生物量达 $3550 \mathrm{~g}(\mathrm{FW}) / \mathrm{m}^{2}$, 占绝对优势, 狐尾藻和苦草的生物量也比较高, 分别为 2148 和 $1980 \mathrm{~g}(\mathrm{FW}) / \mathrm{m}^{2}$, 其他伴生种分别为黑藻 $\left(1048 \mathrm{~g}(\mathrm{FW}) / \mathrm{m}^{2}\right)$ 、金鱼藻 $\left(505 \mathrm{~g}(\mathrm{FW}) / \mathrm{m}^{2}\right)$ 、马来眼子菜 $\left(480 \mathrm{~g} / \mathrm{m}^{2}\right)$ 以及菱 $(75 \mathrm{~g}$ $\left.(\mathrm{FW}) / \mathrm{m}^{2}\right)$ 等.

\section{4 讨论}

自 1950s 以来,洱海的水位、水质和透明度已发生了很大变化, 而自 1990s 后期以来洱海实施的治理和 修复工程 (如“双取消” : 取缔机动捕捞、取消网箱养鱼; “三退三还” : 退耕还林/湖、退塘还湖、退房还湿地; 保护治理洱海的“六大工程” : 建设城镇环保基础设施、综合整治主要人湖河流、全面治理农业农村面源污 染、加快推进生态修复工程、加大洱海流域水土保持综合治理、强化环境管理与能力建设) 以及最低运行水 位的调整同样给洱海带来了深刻影响.

水位是影响水生植物分布的决定因素, 它直接决定了水生植物分布的范围. 同时, 水位的变化也会影响 洱海的纳污能力, 进而影响水质和透明度的变化, 也间接影响水生植物的分布. 自 1952 年以来洱海的平均 水位变化可分为四个阶段 ${ }^{[12-13]}: 1952-1974$ 年间虽在西洱河口有闸控制,但洱海基本上还是个自然湖泊,其 间水位虽然整体上趋于下降, 但其水量能够维持其动态平衡, 水位变幅小, 平均水位为 $1974.05 \mathrm{~m} .1970 \mathrm{~s}$ 开 挖西洱河, 随着西洱河梯级电站相继投人运行, 平均水位迅速下降, 1982 年平均水位达到 $1971.10 \mathrm{~m}, 1975-$ 1982 年的 8 年间下降了 2.99 m. $1983-2003$ 年水位回涨,但水位变化较大且偏低, 21 年平均水位为 $1972.63 \mathrm{~m}$. 2004 年以来随着洱海管理条例修正案的实施 (规定洱海最低运行水位为 $1972.60 \mathrm{~m}$, 最高运行水位为 
$1974.30 \mathrm{~m}$ ), 水位继续回涨, 但由于工农业生产和居民用水的增加以及受降雨的影响, 到 2008 年水位达 $1973.97 \mathrm{~m}$, 基本接近历史水平 ( 图 6).

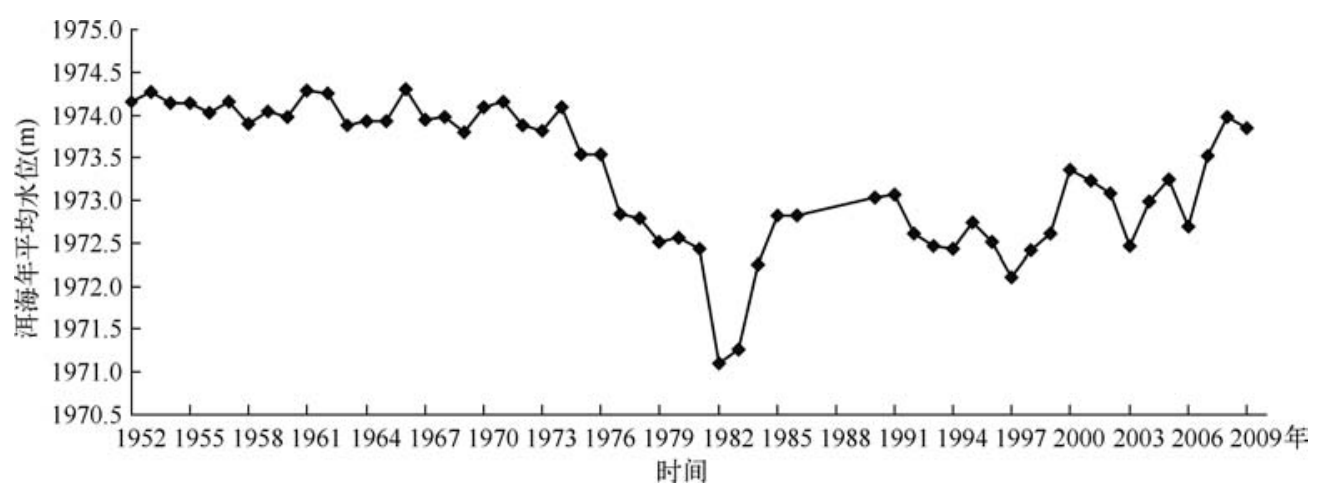

图 61952 至 2009 年间洱海年平均水位变化

Fig. 6 Annual variation of mean water level in Lake Erhai from 1952 to 2009

水质和透明度也是影响水生植物分布的重要因素, 随着流域内工农业生产发展和人口增长, 水土流失、 农业汇水、工业废水、生活污水等携带大量营养盐涌人洱海, 使得进人湖泊的氮、磷等营养盐浓度不断增加; 而 $1980 \mathrm{~s}$ 后期开展的网箱养鱼, 不仅加快了水生植物体内储存的营养盐的释放, 同时, 扒捞水草也扰动了底 泥, 促进了沉积物中营养盐的释放; 另外, 湖滨带挖塘养鱼、以湖水置换塘水, 不仅破坏了湖滨带完整性, 也 将养殖水体的营养盐排放到湖里; 湖滨带开垦既削弱了湖滨带的固有功能, 也使污染物和营养盐直接人湖、 从 1957 到 1997 年, 湖水中三态氮浓度增加近 20 倍, 磷酸盐浓度增加了 4.1 倍 ${ }^{[10]}$, 由贫营养到中营养水平, 到 2003 年有些指标达到中富营养水平. 2004 年后, 随着洱海管理条例修正案的实施, 水位的提高, 洱海水质 大体维持在 II-III类之间 ${ }^{[14]}$.

随着水位的涨落、水质和透明度变化、人类对洱海资源开发强度的变化以及后来的治理和修复工程使 洱海水生植物的种类组成、优势种群演进、群落结构以及分布面积都发生了深刻变化 ${ }^{[15]}$, 特别是后来的“三 退三还”、生态修复工程和运行水位调整, 使洱海水生植物的变化与 $1990 \mathrm{~s}$ 后期相比又出现了新的特点, 主 要表现在以下几个方面:

(1) 种类有所增加. 洱海湖滨带的水生植物种类也经历了由多到少, 再增多的过程 (表 1), 虽然不同作 者的调查范围和方法不尽相同, 有些未给出植物名录, 但这种变化大体上与水位涨落和水质以及人为的影 响过程相吻合. 本次调查获得的植物种类最多, 有维管植物 47 科 108 属 145 种, 其中沉水植物 26 种, 浮叶植

表 1 不同时期洱海水生植物科、属、种数比较

Tab. 1 Comparison of the amount in families, genera and species of aquatic vegetation in different phases of Lake Erhai

\begin{tabular}{|c|c|c|c|c|c|c|c|c|c|}
\hline 时间 & 科数 & 属数 & 种数 & 沉水植物 & 浮叶植物 & 漂浮植物 & 挺水植物 & 湿生植物 & 备注 \\
\hline 1977 年 ${ }^{[6]}$ & 19 & 30 & 40 & 15 & 3 & 5 & 4 & 13 & (1) \\
\hline 1983 年 ${ }^{[7]}$ & 17 & 24 & 32 & 13 & 3 & 4 & 4 & 8 & (1) \\
\hline 1986 年 $[8]$ & 26 & 44 & 61 & 19 & 7 & 6 & 11 & 18 & (1) \\
\hline 1996 年 $[9]$ & 19 & 26 & 35 & 12 & 4 & 5 & 6 & 8 & (2) \\
\hline 1997 年 ${ }^{[10]}$ & - & - & 45 & 13 & 5 & 7 & 9 & 11 & (2) \\
\hline 1998 年 ${ }^{[11]}$ & 6 & 6 & 13 & 13 & - & - & - & - & (1) \\
\hline 2009 年 & 47 & 108 & 145 & 26 & 7 & 7 & 15 & 75 & (3) \\
\hline
\end{tabular}

(1) 附有植物名录; (2) 未附植物名录; (3) 有植物名录,同时包含湿生乔灌木 15 种. 
物 7 种, 漂浮植物 7 种, 挺水植物 15 种, 湿生植物 75 种, 一方面是由于本次对水线上湖滨带湿地进行了较为 全面的调查, 新增了很多湿生种类; 另一方面是因为经过 “三退三还” 和湖滨带修复工程, 湖滨带生境确实得 到改善, 而修复过程中也人为增加了一些物种, 尤其是一些挺水和湿生类群, 同时, 本次调查也是对以前调 查的总结. 但有些种类还是没有调查到, 如角果藻、水篮等, 扁茎眼子菜 (P. compressus) 也仅见残枝, 曾经繁 盛一时的海菜花, 㿾胗几株, 还是人为种植的. 因此还应该加强土著类群的恢复, 尤其是像海菜花等一些标 志性物种的恢复繁育.

(2) 群落类型与优势种群变化. 本次洱海湖滨带植被分为 15 个群落类型, 与 $1990 \mathrm{~s}$ 后期相比 ${ }^{[9-11]}$, 芦苇 群落得到恢复, 但群落规模有限; 而菰在挺水植物中仍占绝对优势; 原来丰富的六荵稻草 (Leersia hexandra) 群落和酸模叶蓼 (Polygonum lapathifolium) 群落变得稀疏难称群落; 浮叶的眼子菜罕见; 而两栖蓼在洱海湖 滨带的西、南部多有分布, 本次列为一个群落类型; 红线草、穿叶眼子菜和菹草比较稀少, 本次未将其单列为 群落 $^{[11,16]}$; 另外, 像黑藻等一些原来单优的群落, 演变成一些共优的群落类型, 如黑藻一苦草一马来眼子菜群 落, 同时增加了菱-狸藻群落和茨藻-狐尾藻一苦草等群落类型; 优势种群类型也发生了变化, 黄丝草取代苦 草、黑藻占绝对优势, 苦草和金鱼藻分别成为第二、第三优势种, 而黑藻则由 1980s 初的第一优势种降为第四 优势种.

(3) 分布面积和区域变化. 本次调查发现, 洱海湖滨带植物覆盖面积狭窄、水生植物分布面积锐减 (表 2 ). 其中, 湖心平台的沉水植物消失是洱海植被覆盖面积锐减的重要原因 ${ }^{[15]}$, 而造成湖心平台消失的原因, 我们认为可能是由于植被演替和水位、水质变化的共同结果. 湖心平台原来以黑藻占优势演变为黄丝草占

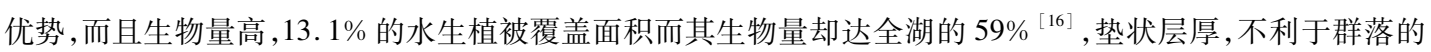
更新, 随着水位提高和透明度降低, 水生植物腐烂衰败, 最终消失. 另外, 随着水位的提高和透明度降低, 洱 海湖滨带的水生植物分布会往高处推移, 在这个变化过程中深水区的分布范围回缩, 但新向上分布的区域 缓慢形成, 在新的分布区成形之前, 湖滨带水生植物的分布面积必然会缩小. 而目前 $8 \%$ 的植被覆盖面积对 洱海水环境改善和生物多样性维护是极为不利的, 在深水区植被难以短期内恢复的情况下, 应加强湖滨湿 地和缓冲区建设, 完善湖滨带屏障功能, 逐步提高水体透明度, 以期提高植被覆盖面积, 我们推测, 洱海的水 生植被覆盖面积应该在 20\%-30\% 为宜. 另外, 分布区域和生物量也发生相应变化, 北部原来由于网箱养鱼 导致的水草覆盖面积及生物量大幅度下降甚至成为 “不毛之地” 状况已经改变 ${ }^{[16]}$, 沙坪湾至长育湾一带为 北部生物量较高的区域 (图 3 ), 南部的罗久邑至石房子, 包括海东湾一带生物量高, 西部以蟠溪至马久邑一 带的湖湾较高, 但总的来看, 南部的生物量依然较高.

表 2 不同时期洱海水生植物分布面积和生物量比较

Tab. 2 Comparison of biomass and distribution area of aquatic vegetation in different phases of Lake Erhai

\begin{tabular}{|c|c|c|c|}
\hline 时间 & 水生植被面积 $\left(\mathrm{hm}^{2}\right)$ & 占湖泊面积 $(\%)$ & 生物量 $\left(\times 10^{4} \mathrm{t}\right)$ \\
\hline 1957 年 ${ }^{[17]}$ & & 水深 $3 \mathrm{~m}$ 以上水域无水生植物 & \\
\hline 1977 年 ${ }^{[6]}$ & & 分布到 6-7 m, 乃至 $10 \mathrm{~m}$ 水深的区域 & \\
\hline 1983 年 ${ }^{[7]}$ & 7727 & 30.9 & 79.96 \\
\hline 1986 年 ${ }^{[8]}$ & 6254 & 25.1 & 47.9 \\
\hline 1996 年 ${ }^{[9]}$ & 4492 & 17.69 & 28.4 \\
\hline 1997 年 ${ }^{[10]}$ & 6533 & 26.58 & 76.5 \\
\hline 1998 年 $[11]$ & 9602.5 & 40.39 & 39.57 \\
\hline 2009 年 ${ }^{\#}$ & 2000 & 8 (湖心平台的水生植被基本消失 ${ }^{[15]}$ ) & 24.99 \\
\hline
\end{tabular}

\#表示湖滨带植被覆盖面积数据由课题提供,测量单位: 中交天津港航勘察设计研究院有限公司.

\section{5 结论}

(1) 洱海湖滨带有维管植物 47 科 108 属 145 种, 其中沉水植物 26 种, 浮叶植物 7 种, 漂浮植物 7 种, 挺 
水植物 15 种, 湿生植物 75 种; 虽经生态修复, 原有的土著类群还没有得到有效恢复, 需要加强像海菜花等标 志性物种的恢复繁育.

(2) 洱海湖滨带植被分为 15 个群落类型, 湿生、挺水植物群落类型单调, 原来的六苑稻草群落、眼子菜 群落、角果藻群落和红线草群落消失, 单优的群落减少、共优群落增加, 反映了湖滨带植被在动荡变化中; 黄 丝草占绝对优势,苦草和金鱼藻分别成为第二、第三优势种,而黑藻则降为第四优势种.

（3）洱海湖滨带植被覆盖面积仅有 $8 \%$, 对洱海水环境改善和生物多样性维护是极为不利的, 应加强湖 滨湿地和缓冲区建设,完善湖滨带屏障功能,逐步提高水体透明度, 以期提高植被覆盖面积.

(4) 北部湖湾区物种数和生物量较大, 种数 11 个, 平均生物量 $12.5 \mathrm{~kg}(\mathrm{FW}) / \mathrm{m}^{2}$, 但总的来看, 南部的 生物量依然较高.

致谢: 感谢中国环境科学院储昭升博士作为课题负责人在洱海考察工作中给予的支持和帮助! 感谢中国环 境科学院洱海工作站的叶碧碧、贾永健、尹严振、杨青、袁桂香等研究生在植被调查中给予的帮助! 感谢两 位审稿专家对论文修改提出的宝贵意见和建议!

\section{6 参考文献}

[ 1 ] 叶 春, 金相灿, 王临清等. 洱海湖滨带生态修复设计原则与工程模式. 中国环境科学, 2004, 24(6): 717-721.

[ 2 ] 颜昌宙, 金相灿, 赵景柱等. 湖滨带的功能及其管理. 生态环境, 2005, 14(2) : 294-298.

[ 3 ] 王云飞, 潘红胥, 吴庆龙等. 人类活动对洱海的影响及对策分析. 湖泊科学, 1999, 11(2): 123-128.

[4] Hilt S, Gross EM, Hupfer M et al. Restoration of submerged vegetation in shallow eutrophic lakes - A guideline and state of the art in Germany. Limnologica, 2006, 36: 155-171.

[ 5 ] Gulati RD, Pires LMD, Van Donk E. Lake restoration studies: Failures, bottlenecks and prospects of new ecotechnological measures. Limnologica, 2008, 38 : 233-247.

[ 6 ] 李 恒. 洱海水生植被回顾. 见: 沈仁湘等编. 云南洱海科学论文集. 昆明: 云南民族出版社, 1989: 31-44.

[ 7 ] 戴全裕. 洱海水生植被的初步研究. 见: 沈仁湘等编. 云南洱海科学论文集. 昆明: 云南民族出版社, 1989: 235243.

[ 8 ] 钱德仁. 洱海水生植被考察. 见: 沈仁湘等编. 云南洱海科学论文集. 昆明: 云南民族出版社, 1989: 45-67.

[ 9 ] 董云仙, 谢建平, 董云生等. 洱海水生植被资源及其可持续利用途径. 生态经济, 1996, (5)：15-19.

[10] 吴庆龙, 王云飞. 洱海生物群落的历史演变分析. 湖泊科学, 1999, 11(3) : 267-273.

[11] 胡小贞, 金相灿, 杜宝汉等. 云南洱海沉水植被现状及其动态变化. 环境科学研究, 2005, 18(1) : 1-5.

[12] 沈仁湘. 洱海水位对环境的影响. 见: 沈仁湘等编. 云南洱海科学论文集. 昆明: 云南民族出版社, 1989: 93-99.

[13] 马根连. 提高运行水位对洱海水环境的影响分析 (云南省水文水资源局大理分局) (www. wcb. yn. gov. cn/slsd/ swzy/4476. html 2009-09-22).

[14] 韩 涛, 彭文启, 李怀恩等. 洱海水体富营养化的演变及其研究进展. 中国水利水电科学研究院学报, 2005, 3(1) : 71-73.

[15] 杨 彪. 洱海湿地保护治理的现状与对策. 四川林勘设计, 2009, (1) : 57-60.

[16] 戴自福, 沙 隽, 李 斌等. 洱海水生维管束植物资源种群动态变化调查研究. 见: 白建坤等编. 大理洱海科学 研究. 北京: 民族出版社, 2003: 97-101.

[17] 黎尚豪, 俞敏娟, 李光正等. 云南高原湖泊调查. 海洋与湖沼, 1963, 5(2) : 87-113. 